\title{
Fertilizer type and species composition affect leachate nutrient concentrations in coffee agroecosystems
}

\author{
Katherine L. Tully $\cdot$ Stephen A. Wood • \\ Deborah Lawrence
}

Received: 28 June 2012/Accepted: 30 April 2013/Published online: 15 May 2013

(C) Springer Science+Business Media Dordrecht 2013

\begin{abstract}
Intensification of coffee (Coffea arabica) production is associated with increases in inorganic fertilizer application and decreases in species diversity. Both the use of organic fertilizers and the incorporation of trees on farms can, in theory, reduce nutrient loss in comparison with intensified practices. To test this, we measured nutrient concentrations in leachate at 15 and $100 \mathrm{~cm}$ depths on working farms. We examined (1) organically managed coffee agroforests $\left(38 \mathrm{~kg} \mathrm{~N} \mathrm{ha}^{-1}\right.$ year $\left.^{-1} ; n=4\right)$, (2) conventionally managed coffee agroforests (96 kg N ha ${ }^{-1}$ year $\left.^{-1} ; n=4\right)$, and (3) one conventionally managed monoculture coffee farm in Costa Rica (300 kg N ha ${ }^{-1}$ year $\left.^{-1}\right)$. Concentrations of nitrate $\left(\mathrm{NO}_{3}{ }^{-}-\mathrm{N}\right)$ and phosphate $\left(\mathrm{PO}_{4}{ }^{3-}-\mathrm{P}\right)$ were higher in the monoculture compared to agroforests at both depths. Nitrate concentrations were higher in conventional than organic agroforests at $15 \mathrm{~cm}$ only. Soil
\end{abstract}

K. L. Tully $(\varangle) \cdot$ S. A. Wood

Agriculture and Food Security Center, The Earth Institute, Columbia University, New York, NY 10025, USA

e-mail: ktully@columbia.edu

\section{S. A. Wood}

Department of Ecology, Evolution \& Environmental Biology, Columbia University, New York, NY 10027, USA

D. Lawrence

Department of Environmental Sciences, University of Virginia, Charlottesville, VA 22904, USA solutions collected under nitrogen (N)-fixing Erythrina poeppigiana had elevated $\mathrm{NO}_{3}{ }^{-}-\mathrm{N}$ concentrations at $15 \mathrm{~cm}$ compared to Musa acuminata (banana) or Coffea. Total soil $\mathrm{N}$ and carbon (C) were also higher under Erythrina. This research shows that both fertilizer type and species affect concentrations of $\mathrm{N}$ and $\mathrm{P}$ in leachate in coffee agroecosystems.

Keywords Agroforestry - Monoculture - Coffee . Leaching $\cdot$ Lysimeters $\cdot$ Fertilizer $\cdot$ Organic agriculture

\section{Introduction}

In Latin America coffee (Coffea arabica) is traditionally cultivated in an agroforest, cropped under the shade of a variety of overstory tree species. However, in response to increases in global demand, coffee farming has intensified through the adoption of highyielding varieties, elimination of shade trees to reduce competition for resources and light, and addition of large quantities of mineral nitrogen $(\mathrm{N})$ fertilizer (200-300 kg N ha ${ }^{-1}$ year $^{-1}$ as a conservative estimate of upward bounds; Reynolds-Vargas and Richter 1995). Isotopic tracer studies from these intensified coffee agroecosystems indicate that only $30-40 \%$ of the applied $\mathrm{N}$ is incorporated into aboveground biomass, and as much as $50 \%$ of the nitrate $\left(\mathrm{NO}_{3}{ }^{-} \mathrm{-N}\right)$ applied is leached below the crop root zone (Sommer 1978; Salas et al. 2002). Annual $\mathrm{NO}_{3}{ }^{-}-\mathrm{N}$ leaching losses tend to be higher in conventional coffee 
monocultures than in agroforests that receive similar quantities of mineral $\mathrm{N}$ (Babbar and Zak 1995; Harmand et al. 2007). Unlike $\mathrm{NO}_{3}{ }^{-} \mathrm{N}$, phosphate $\left(\mathrm{PO}_{4}{ }^{3-}-\mathrm{P}\right)$ has received less attention. In phosphorus (P)-poor tropical soils, $\mathrm{PO}_{4}{ }^{3-}$-P leaching is assumed to be negligible (Radulovich and Sollins 1991). However, in agricultural systems, where $\mathrm{P}$ additions can vary by an order of magnitude among farms, leaching may be substantial; therefore, it is important to assess the effects of different management strategies on this process.

The form in which $\mathrm{N}$ is applied may differentially impact leaching since mineral fertilizers are applied in a form that is both readily available to plants and highly susceptible to leaching. Thus, $\mathrm{NO}_{3}{ }^{-} \mathrm{N}$ is likely to move quickly through these systems. Organic fertilizers, by contrast, must undergo chemical transformations before they can be assimilated by plants, making them less susceptible to leaching. Many studies in temperate regions have shown that the addition of organic fertilizers can have positive impacts on soil organic matter (SOM; Clark et al. 1999), microbial biomass (Fließach and Mader 2000), soil biological activity (Fließach et al. 2007), mineralizable N (Clark et al. 1998), cation exchange capacity (Reganold et al. 1993), water-holding capacity (Liebig and Doran 1999), and permeability (Drinkwater et al. 1995). Very few studies evaluating the impacts of organic farming practices have been conducted in tropical regions (but see Payán et al. 2009). This study will assess how organic and conventional farming practices (specifically the application of organic vs. mineral fertilizers) alter leachate and soil nutrient dynamics in coffee agroecosystems.

In addition to fertilizer form, biotic factors, such as community composition, are likely to control the amount of nutrients that leach through the soil profile. Agroforests are distinguished from monocultures by their structural and species diversity. Greater aboveground biomass and niche complementarity leads to resource partitioning among functionally different species that can use resources in different ways (Cardinale et al. 2007, 2012; Reich et al. 2012). Increased species diversity (even at low levels) should therefore lead to lower amounts of leaching through increased resource use efficiency at the community scale (Ewel and Bigelow 2011). Deeply rooted shade trees in agroforests can access water and nutrients stored beyond the reach of coffee plants reducing leaching (Berendse 1979; Seyfried and Rao 1991; Van Noordwijk et al. 1996; Schroth et al. 2001). Nutrient dynamics in these systems will be affected by the diversity of functional traits present and expressed (Hillebrand and Matthiessen 2009). The diversity of plant functional traits (e.g. N-fixation, water use efficiency, foliar $\mathrm{C}: \mathrm{N}$ ratios, etc.) can alter the physical environment and microclimate through effects on percent shade cover (Vanlauwe et al. 1997) and standing biomass (Eviner and Chapin 2003). There is also tentative evidence that plant community composition and diversity can alter microbial communities, with potential implications for nutrient cycling (Innes et al. 2004; Carney and Matson 2004; Bremer et al. 2007; Lamb et al. 2011).

Finally, hardly any research (temperate or tropical) has measured leaching losses from organic and conventional farming systems, and leaching estimates are typically based on nutrient budgets (but see Stopes et al. 2002 and Torstensson et al. 2006). Many factors in the soil that are not reflected in nutrient budgets may be crucial to the processes regulating $\mathrm{N}$ and $\mathrm{P}$ leaching (Ulén et al. 2005; Aronsson et al. 2007). We measured several of these soil characteristics to determine their ability to predict leachate nutrients across different management scenarios.

Although a spectrum of management systems exists for coffee agroecosystems, no research has explored how multiple factors-in this case, fertilizer form, species composition, and soil characteristics (i.e. C, N, $\mathrm{P}$, gravimetric soil moisture, and $\mathrm{pH}$ )—drive patterns in nutrient concentrations in leachate. Understanding how these factors regulate leaching losses is critical for the design and implementation of sustainable agricultural practices and policies in the tropics.

\section{Materials and methods}

Study sites

This study was conducted in three locations near Turrialba, Costa Rica $\left(9^{\circ} 53^{\prime} \mathrm{N} 83^{\circ} 41^{\prime}-83^{\circ} 42^{\prime} \mathrm{W}\right.$; Fig. 1). Farms were located within three $\mathrm{km}$ of each other $\left(9^{\circ} 51^{\prime}-9^{\circ} 54^{\prime} \mathrm{N}, 83^{\circ} 41^{\prime}-83^{\circ} 42^{\prime} \mathrm{W}\right)$. The altitude of sites ranged from 783 to $1,017 \mathrm{~m}$ above sea level. Soils are of volcanic origin and are characterized as Typic Humitropepts (Selvaradjou et al. 2005) with a 
clay-loam texture. The study region receives on average 2,600 $\mathrm{mm}$ of rainfall per year and has a mean annual temperature of $22.6^{\circ} \mathrm{C}$ (CATIE meteorological data). Rainfall is seasonal, and the dry season extends from February through May. This study was conducted between September 2008 and October 2009 , over a year that was wetter than average, with a cumulative rainfall of $3,530 \mathrm{~mm}$ from lysimeter installation to final collection. During the study period, the region experienced an unusually wet December $(708 \mathrm{~mm})$ and February $(544 \mathrm{~mm})$ and an extremely dry April (39 mm; Fig. 7 in Appendix). When soils are at field capacity, monthly evapotranspiration in coffee agroforests is roughly $70-75 \mathrm{~mm}(2-3 \mathrm{~mm}$ per day; Goméz-Delgado et al. 2011); therefore, plants likely experienced water stress between April and May of 2009. Soil solutions were difficult to collect at this time due to highly negative capillary pressure of remaining soil water.

After farmer interviews and preliminary sampling (Tully and Lawrence 2011), four organically managed

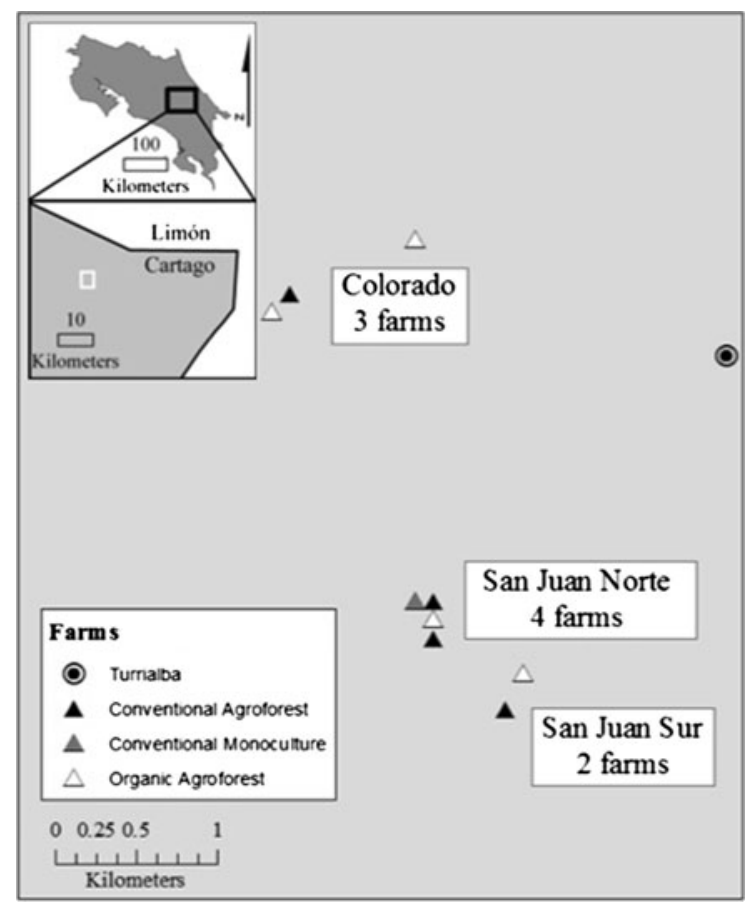

Fig. 1 Map of farm locations in Central Valley of Costa Rica indicating the locations of the three regions where coffee farms were selected for instrumentation in 2008. All farms are located between 783 and 1,017 masl. Four are conventional agroforests, four are organic agroforests, and one is a conventional coffee monoculture and four conventionally managed coffee agroforests, and one conventionally managed coffee monoculture were selected for instrumentation (Table 1). Thus, we examined three farm management types: (1) organic agroforests (OAF) where Coffea is cultivated under the canopy of shade trees in the absence of synthetic fertilizers and pesticides; (2) conventional agroforests (CAF) where Coffea is cultivated under the canopy of shade trees in the presence of synthetic fertilizers and pesticides; (3) conventional monocultures (MONO) where Coffea is grown in the absence of other species (trees) and in the presence of synthetic fertilizers and pesticides. In the agroforests, Coffea is cultivated at a density of 3,300-6,600 plants ha ${ }^{-1}$ (Table 1) under a combination of Erythrina poeppigiana and Musa acuminata (banana). Nitrogen-fixing Erythrina represents $49 \%$ of the total shade stem (non-Coffea) density in conventional agroforests and $45 \%$ of the total shade stem density in organic agroforests, with the rest consisting of Musa (Table 1). Shade trees are pruned two to three times a year, which can provide as much as $70-90 \mathrm{~kg}$ of $\mathrm{N} \mathrm{ha}^{-1}$ year $^{-1}$ (Tully and Lawrence 2011, but see Tully et al. 2012 for timing of pruning). On average, conventional agroforests received $96 \mathrm{~kg}( \pm 16)$ of $\mathrm{N}$ and $18 \mathrm{~kg}( \pm 5)$ of $\mathrm{P} \mathrm{ha}^{-1}$ year $^{-1}$ in the form of mineral fertilizer (Table 1; Tully et al. 2013). Organic agroforests received an average of $38 \mathrm{~kg}( \pm 20)$ of $\mathrm{N}$ and $16 \mathrm{~kg}( \pm 7)$ of $\mathrm{P} \mathrm{ha}^{-1}$ year $^{-1}$ in the form of manure, compost, and/or fermented coffee husks (called broza locally). The conventional monoculture received $300 \mathrm{~kg} \mathrm{~N}$ and $62 \mathrm{~kg}$ of $\mathrm{P} \mathrm{ha}^{-1}$ year $^{-1}$. Farmers in this region tend to apply fertilizer at one time (basal application), typically in January (Tully et al. 2012).

\section{Tension lysimeters}

Tension lysimeters use suction to collect water from the soil matrix and were constructed by attaching ceramic cups (SoilMoisture Corp., Goleta, CA) to a 4.2-cm diameter (Schedule 40) polyvinyl chloride (PVC) pipe tube sealed at the end with a rubber stopper (1-hole, \#7.5). Farmers apply organic and mineral fertilizer directly to the base of Coffea plants. In order to capture fertilizer dynamics, we placed lysimeters within $30 \mathrm{~cm}$ of the base of Coffea plants in all farms. Conventional agroforests were heavily instrumented with additional lysimeters installed within $30 \mathrm{~cm}$ of the stems of Erythrina and Musa (2 depths per 


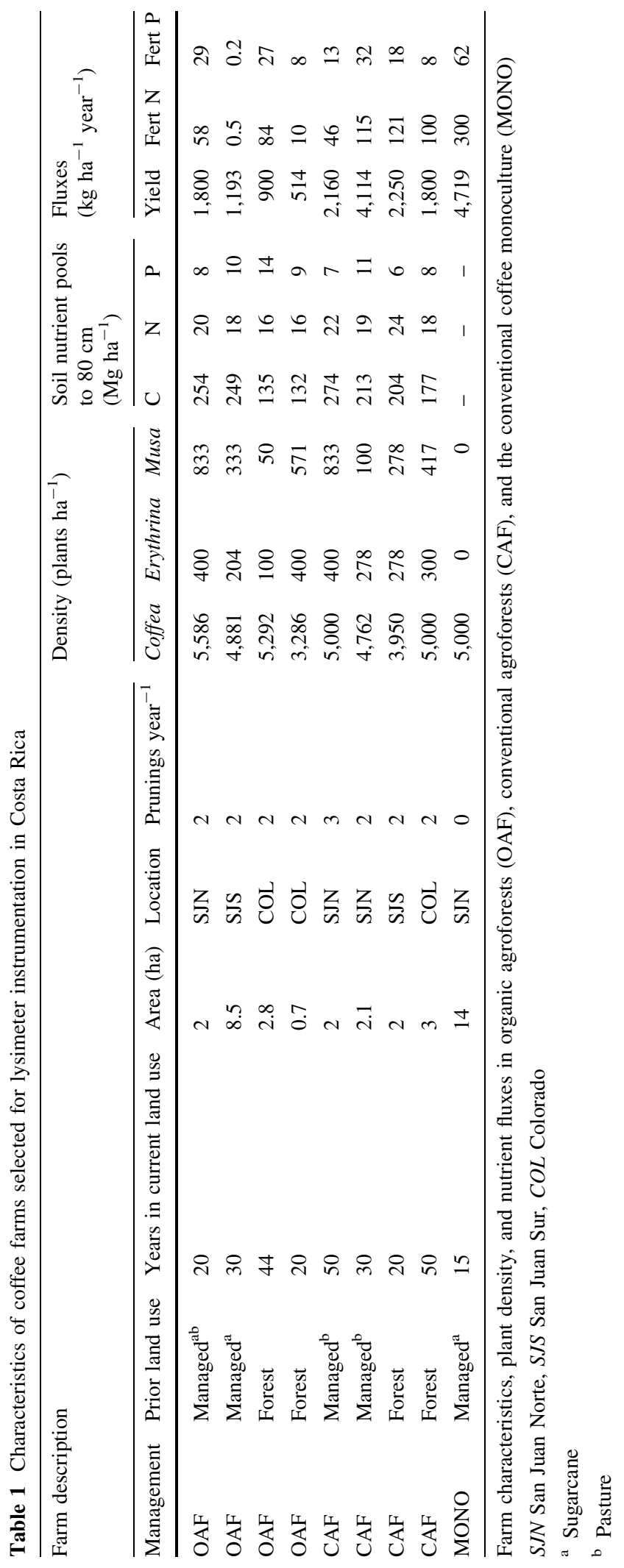


Fig. 2 Diagram of lysimeter sampling design in coffee farms in Costa Rica. Lysimeter sampling design in a conventional agroforests, $\mathbf{b}$ organic agroforests, and $\mathbf{c}$ the conventional monoculture. The design at the farm level is shown in $\mathbf{d}$ Locations of gravity lysimeters are indicated by black triangles (all at $15 \mathrm{~cm}$ ) and rectangles indicate locations of tension lysimeters (at 15 and $100 \mathrm{~cm}$ depth). In agroforests, a pair of gravity lysimeters was installed at $15 \mathrm{~cm}$ below Coffea and adjacent Musa, Coffea and adjacent Erythrina, and Coffea $5 \mathrm{~m}$ from the nearest shade tree. Only tension lysimeters were installed in the monoculture (a) Conventional Agroforest
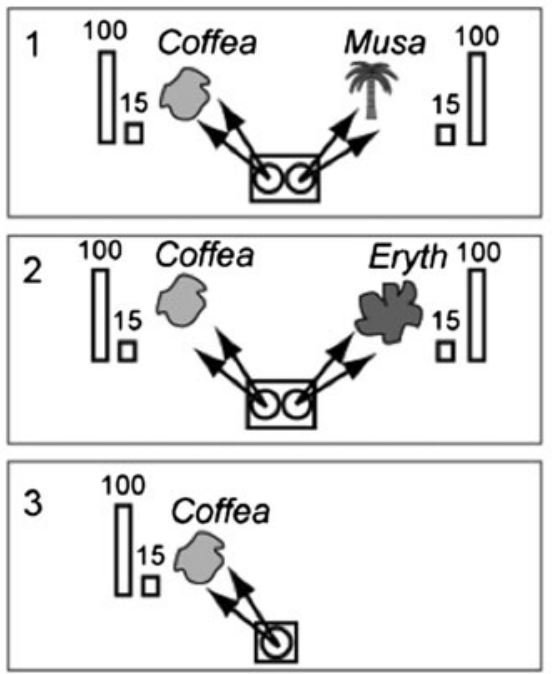

(c) Conventional Monoculture

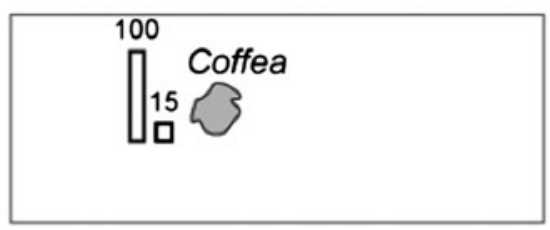

Legend

Coffea arabica

Musa acuminata

Erythrina poeppigiana (b) Organic Agroforest
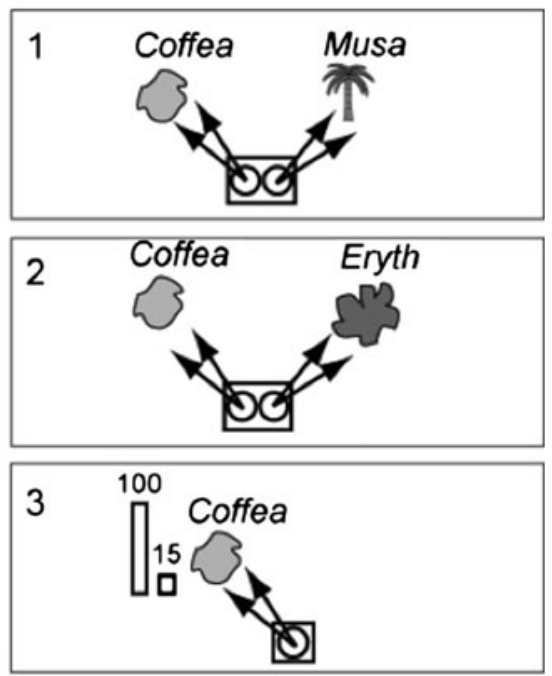

(d) Experimental Design

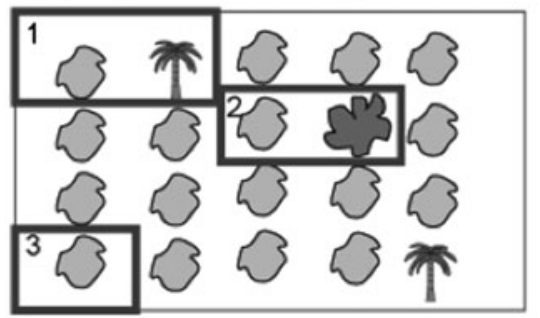

OOgravity lysimeter collection bottle

A gravity lysimeters

$\square$ tension lysimeter plant $\times 5$ species combinations; $n=10$ per farm; Fig. 2a). We examined soil solutions at $100 \mathrm{~cm}$ as (1) $75 \%$ of total fine root biomass in Coffea is was concentrated in the top $100 \mathrm{~cm}$ of soil (Siles et al. 2010); (2) $80 \%$ of Erythrina roots are concentrated in the first $20 \mathrm{~cm}$ (Chesney 2008); and (3) $70 \%$ Musa roots are concentrated in the first $40 \mathrm{~cm}$ (Draye 2002). Roots of both Erythrina and Musa can extend below the Coffea rooting zone of $60 \mathrm{~cm}$ (Chesney 2008; Araya 2005), but become rare at $100 \mathrm{~cm}$ depth. Thus, we assumed that soil solutions collected at $100 \mathrm{~cm}$ were indicative of the soluble nutrient concentrations lost from the system. In organic agroforests, a pair of tension lysimeters (15 and $100 \mathrm{~cm})$ was installed within $30 \mathrm{~cm}$ of the base of the previously selected "distant Coffea plant" (a plant located at least $5 \mathrm{~m}$ from nearest shade tree; Fig. 2b), but tension lysimeters were not installed in the other species combinations. Lysimeter pairs were installed under two different Coffea plants in the conventional monoculture farm (Fig. 2c).

Tension lysimeters were allowed to equilibrate with their surroundings for one month before collection, after which samples were collected every 4 weeks (starting in September 2008). Lysimeters were filled with distilled water before each sampling period in order to maintain good contact between the lysimeters and the surrounding soil. The day before sample collection, tension lysimeters were purged of any remaining water, and an internal pressure of -0.05 to $-0.06 \mathrm{MPa}$ was applied using a hand-held vacuum pump. Soil solutions were extracted from the lysimeters 
on the following day and were re-filled with distilled water. All samples were frozen until analysis to minimize the conversion of inorganic $\mathrm{N}$ to organic $\mathrm{N}$ by microbes.

\section{Gravity lysimeters}

Gravity lysimeters are frequently used in tropical systems where rainfall is high (Russell and Ewel 1985; Radulovich and Sollins 1991; Campo et al. 2001). To examine the effect of management and species on nutrient concentrations in leachate in surface soils, three lysimeter stations were established in the eight agroforests. A pit was excavated to roughly $80 \mathrm{~cm}$ within $50 \mathrm{~cm}$ of the bases of (1) Coffea beside Erythrina, (2) Coffea beside Musa and (3) the "distant" Coffea plant (Fig. 2a, b). Soil samples were taken at six depths within each pit in order to quantify total soil nutrient pools (Table 1). Gravity lysimeters were not installed in the conventional monoculture, as the owner did not agree to pit excavation in his farm.

Gravity lysimeters were constructed from $4.2-\mathrm{cm}$ PVC tubes cut on an angle to create an oval opening with semi-axis of 10.16 and $5.08 \mathrm{~cm}$. The surface area of the lysimeter exposed to leachate was $40.45 \mathrm{~cm}^{2}$ such that $10 \mathrm{~mm}$ of leachate should yield $40.45 \mathrm{~mL}$. Trenches were dug and lysimeters were installed $15 \mathrm{~cm}$ below the soil surface and roughly $15 \mathrm{~cm}$ from the base of the trunk. Two lysimeters were installed under each species in the pair (e.g. Coffea and adjacent shade tree), and lysimeters from each species were connected to a single one-liter volumetric high-density polyethylene (HDPE) collection bottle by PVC tubing. For example, the two lysimeters under Erythrina were connected to one bottle and the two lysimeters under Coffea were connected to another. A wooden box (internal dimensions: $85 \mathrm{~cm} \times 10 \mathrm{~cm} \times 20 \mathrm{~cm}$ ) was installed in the pit to prevent back-filling, and the HDPE bottles were placed at the bottom of the box. Bottles were treated with three drops of chloroform $\left(\mathrm{CHCl}_{3}\right)$ to prevent bacterial growth, and all parts of the lysimeter were washed in $5 \% \mathrm{HCl}$ prior to deployment. Gravity lysimeters were allowed to equilibrate with their surroundings for one month before collecting the first sample, after which water was allowed to accumulate in the bottle and samples were collected every four weeks (starting in September 2008). At each collection, the volume in the bottles was measured and a sub-sample of soil water was collected for nutrient analysis. Old bottles were replaced with acid-washed $(10 \% \mathrm{HCl})$, chloroform-treated bottles. All samples were frozen prior to analysis.

\section{Soils collection}

Every four weeks (on the same day that tension was applied), soil samples (0-10 $\mathrm{cm}$ depth) were collected from within $1 \mathrm{~m}$ of each lysimeter station. Eight soil cores were collected from each station and composited for a total of three samples per farm, and 14 collections over the course of a year. Field-moist sub-samples of soils were weighed on the same day as collection, oven-dried at $105{ }^{\circ} \mathrm{C}$ until a constant mass was attained, then re-weighed to determine gravimetric soil moisture content (mass water $/$ mass $_{\text {soil }}$ ). Remaining soils were air-dried for three days in an air-conditioned room, and then passed through a $2 \mathrm{~mm}$ mesh sieve. Soil $\mathrm{pH}$ was determined on air-dried sub-samples using a 2:1 water-to-soil slurry.

\section{Nutrient analysis}

Leachate samples from gravity and tension lysimeters were transported to the University of Virginia for nutrient analysis. Samples were filtered through a Whatman filter (No. $42 ; 2.5 \mu \mathrm{m}$ ) to remove any debris. Inorganic $\mathrm{NO}_{3}{ }^{-}, \mathrm{NH}_{4}{ }^{+}$, and $\mathrm{PO}_{4}{ }^{3-}$ in leachate were analyzed on a LACHAT QuikChem (LACHAT Instruments Loveland, CO) on filtered samples. A potassium persulfate digestion (also on filtered samples) converted organic $\mathrm{P}$ to an inorganic form (Hosomi and Sudo 1986). Analyzing this solution on a LACHAT yielded total $\mathrm{P}$ concentrations, which allowed us to calculate organic P. All nutrient concentrations are reported in $\mathrm{mg} \mathrm{L}^{-1}$ (where mass values pertain to $\mathrm{N}$ or $\mathrm{P}$ component of $\mathrm{NO}_{3}{ }^{-}, \mathrm{NH}_{4}{ }^{+}, \mathrm{PO}_{4}{ }^{3-}$ ).

Bioavailable soil $\mathrm{P}$ was determined using a modified Bray-extraction on sub-samples of air-dried soil. Approximately three grams of sieved, air-dried soils were shaken for one minute in $25 \mathrm{~mL}$ of a $0.03 \mathrm{~mol} \mathrm{~L}^{-1} \mathrm{NH}_{4} \mathrm{~F}$ and $0.025 \mathrm{~mol} \mathrm{~L}^{-1} \mathrm{HCl}$ solution (Bray and Kurtz 1945). Extracts were filtered and $\mathrm{P}$ concentration was determined colorimetrically using a molybdate blue methodology on an Alpkem Flow Solution IV Autoanalyzer (OI Analytical, College Station, Texas, USA). A portion of soil was also ground to $<145 \mu \mathrm{m}$ and dry-combusted on an elemental analyzer to determine total $\mathrm{N}$ and $\mathrm{C}$. All data 
are reported on an oven-dry mass basis. Nutrient ratios $(\mathrm{C}: \mathrm{N}$ or $\mathrm{N}: \mathrm{P})$ are reported on a molar basis.

Statistical approach

\section{Tension lysimeters}

We used a generalized linear mixed model (GLMM) approach to assess the effect of management on nutrient concentrations in leachate, measured in tension lysimeters (Fig. 2 a3, b3, and c). Because of a non-Gaussian error structure, we fit our GLMMs with a Poisson distribution, which best fit the data. Since Poisson distributions require an integer response, we multiplied the leachate concentration values by 100 and rounded. This preserved the two significant digits with which the original, non-integer data were reported, but allowed the data to be run in a Poisson model. We also tested lognormal and Gaussian error structures, none of which significantly impacted the results. We decided to use the Poisson model because it had the best qualitative fit to the data.

A second motivation for the selection of the GLMM was to account for the unbalanced study design. We identified four replicate farms of each type of agroforest with one tension lysimeter pair each (one at $15 \mathrm{~cm}$ and one at $100 \mathrm{~cm}$; four conventional agroforests and four organic agroforests). However, only one conventional monoculture farmer agreed to participate in the study, so we installed two lysimeter pairs on this farm (Note: the monoculture farm is on average five times larger than individual agroforests). The GLMM, unlike an analysis of variance (ANOVA)-based approach, is flexible enough for unbalanced designs. We included two random effects: date and individual lysimeter, nested within farm, to account for variability among instruments. In all models, the leaching response variables were restricted to values greater than zero. In some cases, concentrations of inorganic $\mathrm{P}$ were calculated to be slightly higher than total $\mathrm{P}$ (leading to a negative value for organic $\mathrm{P}$ ) due to variation in colorimeter calibration and low concentrations of $\mathrm{P}$ in leachate. Any negative organic $\mathrm{P}$ values were dropped from the analysis as were the inorganic and total $\mathrm{P}$ values associated with them.

The GLMM models were fit using a Markov Chain Monte Carlo (MCMC) approach (Zuur et al. 2009; see Clark 2005 for an explanation of MCMC in an ecological context) using the "MCMCglmm" package
(Hadfield 2010) for the $\mathrm{R}$ statistical programming environment (R Development Team 2012). We selected the MCMC approach to modeling GLMMs because the F-statistics associated with GLMMs in the widely used "Ime4" package are not considered valid because they assume fixed denominator degrees of freedom in the calculation of the F-statistic, which varies as a function of degrees of freedom, thus making associated $P$ values anti-conservative (Baayen et al. 2008). Researchers have begun to circumvent this challenge by assessing significance of these GLMMs with MCMC approaches (Bradford et al. 2012). MCMC techniques offer a robust alternative strategy for marginalizing the model random effects and identifying response variable likelihood (Browne and Draper 2006). The MCMCglmm package has the added benefit of allowing for alternative random effects structures, including the nested random effects used in this study. We report $P$ values derived from the MCMC estimation of a posterior distribution; these $P$ values have similar interpretation to classical $P$ values. We considered coefficients with $P<0.05$ significant and coefficients with $P<0.10$ marginally significant (Hurlbert and Lombardi 2009).

To examine species effects, nutrient concentrations in leachate collected from tension lysimeters (at both depths) in conventional agroforests, we used GLMMs with a Poisson error structure (with species and depth as main effects, time as random effect, and lysimeters nested within farms; Fig. 2b). We tested five species and/or species combinations: Erythrina, Musa, distant Coffea plant, Coffea adjacent to Erythrina, and Coffea adjacent to Musa. Each of the models we used is represented in Fig. 8 in Appendix.

\section{Gravity lysimeters}

We also used GLMMs to assess the impact of both management type and species on nutrient concentrations in leachate, measured by gravity lysimeters. Time was included as a random effect and individual lysimeters were nested within farm. We used the same MCMC approach to estimate significance values as was used in the tension lysimeter models.

\section{Comparing tension and gravity lysimeters}

We fit a LMM using a similar approach to compare nutrient concentrations collected at $15 \mathrm{~cm}$ from tension and gravity lysimeters. All of the data were 
lognormally distributed, so they were log-transformed (for leachates from both tension and gravity lysimeters) before entering the model.

\section{Soil characteristics}

We were interested in assessing (1) the effect of management and species on soil characteristics (e.g. total N, total C, Bray-P, gravimetric soil moisture, and $\mathrm{pH}$ ) and (2) the relationship between soil characteristics and nutrient concentrations in leachate. For the first analysis, we used a linear mixed model (LMM) approach with management and species as main effects and time and farm as random effects. In this case, farms were blocked by location in order to account for inherent differences in substrate (even though all farms were located within $3 \mathrm{~km}$ of one another; Fig. 1). To disaggregate the effect of different species combinations, which is a three-level variable, on soil properties, we used pairwise $t$ tests with Tukey comparisons between each combination. For $\mathrm{pH}$, we converted to the concentration of $\mathrm{H}^{+}$ions to eliminate confounding results due to the logarithmic scale of the data. Soil data were cleaned by removing any observations of total $\mathrm{N}$ and $\mathrm{C}$ where total carbon was less than $2.5 \%$. These low values for percent carbon are suggestive of instrumentation error.

In the second analysis, we sought to examine the relationship between surface soil $(0-10 \mathrm{~cm}$ depth) characteristics and leachate nutrient concentrations in both gravity and tension lysimeters to explain potential drivers of nutrient loss. We used a GLMM to assess the impact of soil properties on nutrient concentrations in leachate, measured by gravity lysimeters. Fixed effects were reduced from a full model based solely on significance, rather than an information criterion approach. Information criteria, such Akaike's Information Criterion (AIC) penalize models for the number of included variables and are useful when trying to select a parsimonious model; given the small number of possible covariates in our model, we did not feel it was necessary to penalize variable inclusion. Further, we were principally interested in understanding which soil properties affected leachate concentrations, rather than optimize overall model performance, thus making variable significance a more appropriate approach than model information criterion. All statistical analyses were conducted using the R statistical package (www.rproject.org).

\section{Results}

Effects of management on leachate and soil

Nitrate concentrations in leachate were significantly higher in the conventional monoculture compared to the agroforests at both depths $(P=0.02$ at $15 \mathrm{~cm}$ and $P=0.04$ at $100 \mathrm{~cm}$ in tension lysimeters; Fig. 3a; Table 2). These concentrations were nearly three times higher $\left(27 \mathrm{mg} \mathrm{NO}_{3}{ }^{-}-\mathrm{N} \mathrm{L}^{-1}\right)$ than the World Health Organization standards for drinking of $10 \mathrm{mg}$ $\mathrm{NO}_{3}{ }^{-}-\mathrm{N} \mathrm{L} \mathrm{L}^{-1}$ (WHO 1996) in the conventional monoculture at $100 \mathrm{~cm}$. Despite greater $\mathrm{N}$ inputs, conventional agroforests did not have higher $\mathrm{NO}_{3}{ }^{-}-\mathrm{N}$ concentrations than organic agroforests at either depth in tension lysimeters. Concentrations of organic $\mathrm{P}$ were also significantly higher at $15 \mathrm{~cm}$ in the conventional
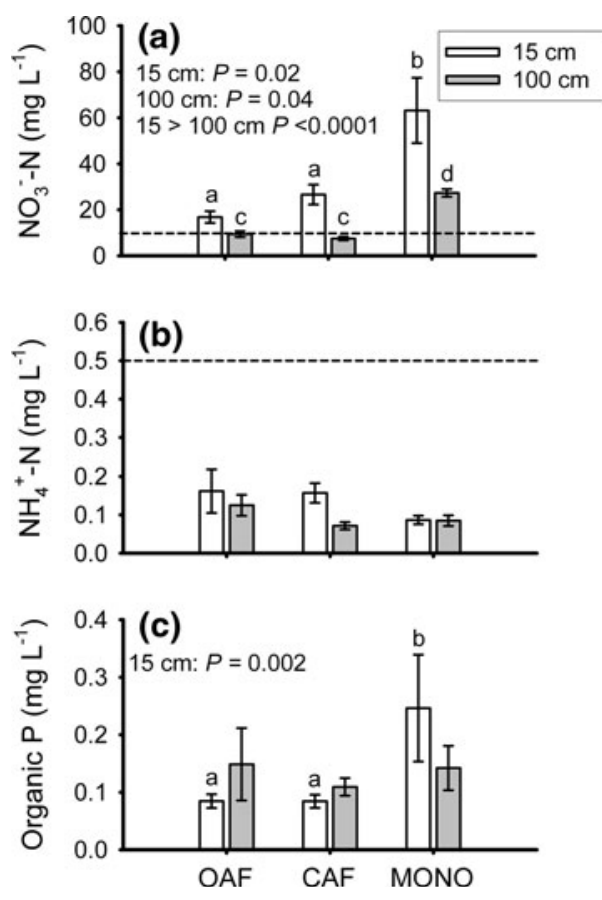

Fig. 3 Mean monthly concentrations of $\mathbf{a ~} \mathrm{NO}_{3}^{-}-\mathrm{N}, \mathbf{b} \mathrm{NH}_{4}{ }^{+}-\mathrm{N}$, and $\mathbf{c}$ Organic $\mathrm{P}$ in leachate collected from tension lysimeters at 15 (white bars) and $100 \mathrm{~cm}$ (grey bars) depth in organic agroforests (OAF), conventional agroforests (CAF), and coffee monocultures (MONO). Dashed lines represent the World Health Organization standards for drinking water quality (10 $\mathrm{mg} \mathrm{NO}_{3}^{-}-\mathrm{N} \mathrm{L}^{-1}$ and $0.5 \mathrm{mg} \mathrm{NH}_{4}^{+}-\mathrm{N} \mathrm{L}^{-1}$ ). Values presented are means across farms (within the same management type) and sampling $(n=13)$. Bars represent standard error of the mean. Values that were significantly different at $P<0.05$ are indicated by different letters 


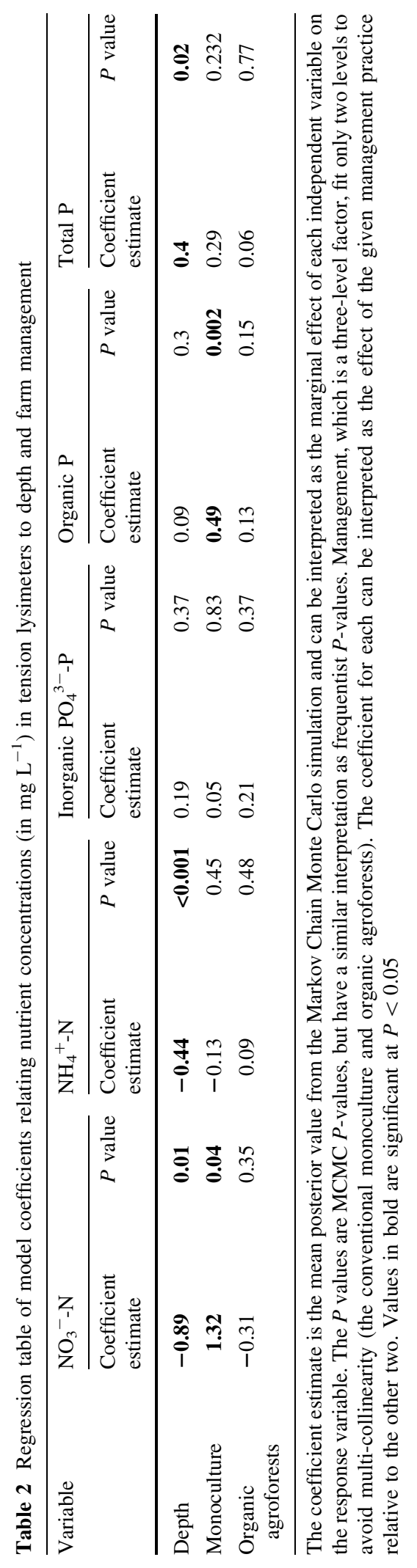



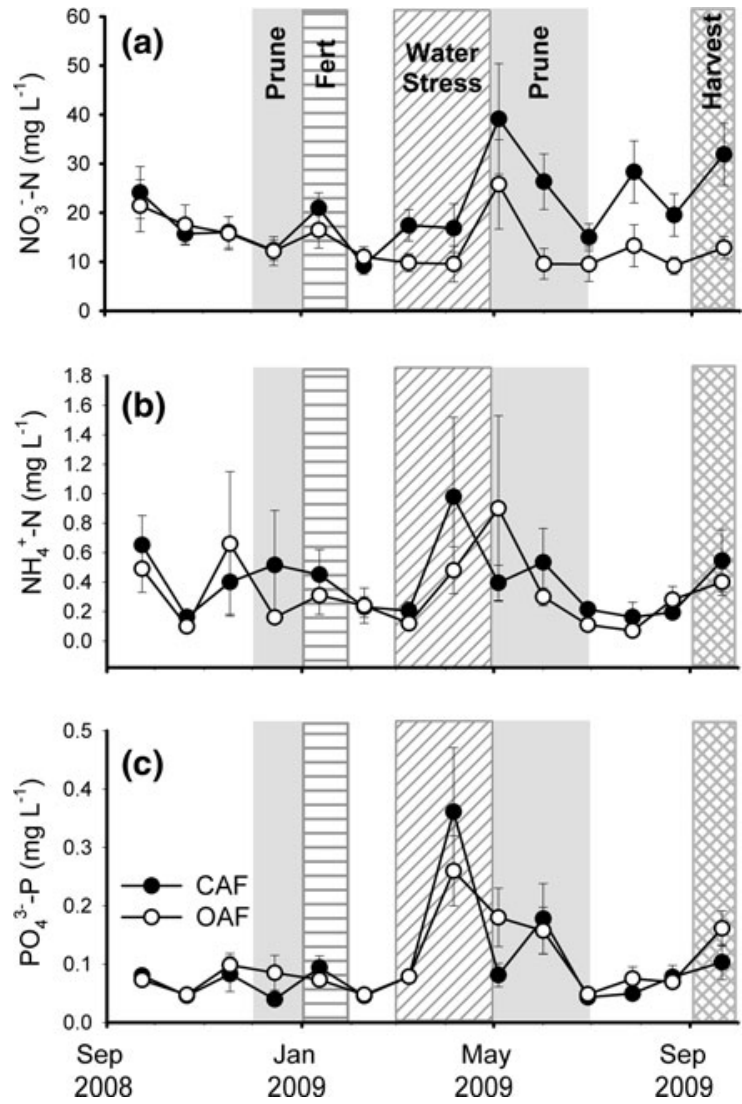

Fig. 4 Nutrient concentrations in gravity lysimeter leachate in coffee agroforests in Costa Rica. Mean concentrations of inorganic a $\mathrm{NO}_{3}^{-}-\mathrm{N}$, b $\mathrm{NH}_{4}{ }^{+}-\mathrm{N}$, and c $\mathrm{PO}_{4}^{3-}-\mathrm{P}$ in leachate $(15 \mathrm{~cm}$; gravity lysimeters) in conventional and organic agroforests (across species) throughout the study period (September 2008-October 2009). Closed circles indicate conventional agroforests (CAF; $n=4)$, and open circles indicate organic agroforests (OAF; $n=4)$. Bars represent standard error of the mean. Diagonal lines represent period of water stress $<100 \mathrm{~mm}$ per month (March through May), shaded areas represent pruning periods (December-January and MayJuly), horizontal lines indicate the primary fertilization event (January-February), and cross-hatches represent harvest period (beginning in September with the harvest peak in November)

monoculture compared to the agroforests $(P=0.001$; Fig. 3c; Table 2). Concentrations of $\mathrm{NH}_{4}{ }^{+}-\mathrm{N}$ did not differ significantly among management types in tension lysimeters (Fig. 3b). Nitrate concentrations in leachate were about two-and-a-half times higher at $15 \mathrm{~cm}$ than they were at $100 \mathrm{~cm}(36$ vs. $15 \mathrm{mg}$ $\left.\mathrm{NO}_{3}{ }^{-}-\mathrm{N} \mathrm{L}^{-1} ; P<0.0001\right)$, and were drawn down by 71,44 , and $57 \%$ from original concentrations in conventional agroforests, organic agroforests, and the conventional monoculture, respectively. The greatest unit reduction in $\mathrm{NO}_{3}{ }^{-}-\mathrm{N}$ concentrations between 15 and $100 \mathrm{~cm}$ occurred in the conventional monoculture (36 $\mathrm{mg} \mathrm{NO}_{3}{ }^{-}-\mathrm{N} \mathrm{L}^{-1}$ difference), with similar reductions in concentrations among organic and conventional agroforests $\left(7\right.$ and $19 \mathrm{mg} \quad \mathrm{NO}_{3}{ }^{-}-\mathrm{N} \mathrm{L}^{-1}$ difference, respectively). As expected, $\mathrm{NH}_{4}{ }^{+}-\mathrm{N}$ concentrations were almost two orders of magnitude lower than $\mathrm{NO}_{3}{ }^{-}-\mathrm{N}$ concentrations, and therefore negligible in terms of $\mathrm{N}$ losses to the system. Concentrations were also below the standard limit of $0.5 \mathrm{mg} \mathrm{NH}_{4}{ }^{+}-\mathrm{N} \mathrm{L}^{-1}$ (WHO 1996) at both depths in all management types (Fig. 3b). Phosphate-P concentrations were also two orders of magnitude lower than $\mathrm{NO}_{3}{ }^{-} \mathrm{-N}$ concentrations, which is not surprising as $\mathrm{P}$ is strongly adsorbed onto the clay minerals of tropical soils.

Gravity lysimeters were only installed at $15 \mathrm{~cm}$ and only in the agroforests, and unlike the tension lysimeters, detected difference between the agroforests. Nitrate concentrations were significantly higher in leachate collected in conventional agroforests (23 mg $\mathrm{NO}_{3}{ }^{-}-\mathrm{N} \mathrm{L} \mathrm{L}^{-1}$ ) than organic agroforests (15 $\mathrm{mg} \mathrm{NO}_{3}{ }^{-}-\mathrm{N} \mathrm{L}^{-1} ; P=0.02$; Fig. 4a), but not for any $\mathrm{NH}_{4}{ }^{+}-\mathrm{N}$ or any form of $\mathrm{PO}_{4}{ }^{3-}$-P (Fig. $4 \mathrm{~b}$ and c; Table 3). There were no significant effects of management on soil properties in organic and conventional agroforests (Fig. 5; Table 5; Fig. 9 in Appendix).

Nitrate concentrations were significantly higher in leachate collected from the tension compared to gravity lysimeters at $15 \mathrm{~cm}(P=0.0001$, mean of 22 and $15 \mathrm{mg} \mathrm{NO}_{3}{ }^{-}-\mathrm{N} \mathrm{L}^{-1}$, respectively). There were no other significant differences in nutrient concentrations in leachate collected from tension and gravity lysimeters.

Effects of species on leachate and soil

There was no significant effect of species on nutrient concentrations in leachate at 15 or $100 \mathrm{~cm}$ collected from tension lysimeters in the conventional farms. Unlike tension lysimeters, gravity lysimeters were installed at the species-level in both conventional and organic agroforests (at $15 \mathrm{~cm}$; Fig. 2a and b). We observed significantly higher $\mathrm{NO}_{3}{ }^{-}-\mathrm{N}$ concentrations under Erythrina $\left(28 \mathrm{mg} \mathrm{NO}{ }_{3}^{-}-\mathrm{N} \mathrm{L}^{-1}\right)$ than any other species or their combination (mean of $17 \mathrm{mg}$ $\mathrm{NO}_{3}{ }^{-}-\mathrm{N} \mathrm{L}^{-1}$ across other species; $P=0.01$; Table 3 ). Organic $\mathrm{P}$ was significantly higher under the CoffeaErythrina combination $\left(0.16 \mathrm{mg}\right.$ organic $\left.\mathrm{P} \mathrm{L}^{-1}\right)$ than any other species or their combination (mean of 
Table 3 Regression table of coefficients of the model relating nutrient concentrations (in $\mathrm{mg} \mathrm{L}^{-1}$ ) in gravity lysimeters to species and management

\begin{tabular}{|c|c|c|c|c|c|c|c|c|c|c|}
\hline \multirow[b]{2}{*}{ Variable } & \multicolumn{2}{|l|}{$\mathrm{NO}_{3}{ }^{-}-\mathrm{N}$} & \multicolumn{2}{|l|}{$\mathrm{NH}_{4}^{+}-\mathrm{N}$} & \multicolumn{2}{|c|}{ Inorganic $\mathrm{PO}_{4}{ }^{3}-{ }_{-} \mathrm{P}$} & \multicolumn{2}{|l|}{ Organic $\mathrm{P}$} & \multicolumn{2}{|l|}{ Total P } \\
\hline & $\begin{array}{l}\text { Coefficient } \\
\text { estimate }\end{array}$ & $P$-value & $\begin{array}{l}\text { Coefficient } \\
\text { estimate }\end{array}$ & $P$-value & $\begin{array}{l}\text { Coefficient } \\
\text { estimate }\end{array}$ & $P$-value & $\begin{array}{l}\text { Coefficient } \\
\text { estimate }\end{array}$ & $P$-value & $\begin{array}{l}\text { Coefficient } \\
\text { estimate }\end{array}$ & $P$-value \\
\hline Management & -0.56 & 0.02 & -0.16 & 0.29 & 0.19 & 0.29 & 0.11 & 0.25 & 0.11 & 0.28 \\
\hline Coffea & -0.08 & 0.84 & 0.06 & 0.81 & -0.17 & 0.55 & 0.09 & 0.56 & -0.03 & 0.85 \\
\hline Erythrina & 0.90 & 0.02 & 0.38 & 0.12 & 0.06 & 0.80 & 0.05 & 0.72 & 0.01 & 0.97 \\
\hline Coffea-Musa & -0.30 & 0.41 & -0.01 & 0.96 & 0.01 & 0.99 & -0.01 & 0.94 & -0.03 & 0.86 \\
\hline Coffea-Erythrina & 0.41 & 0.27 & 0.09 & 0.70 & 0.12 & 0.69 & 0.28 & 0.05 & 0.20 & 0.22 \\
\hline
\end{tabular}

The coefficient estimate is the mean posterior value from the Markov Chain Monte Carlo simulation and can be interpreted as the marginal effect of each independent variable on the response variable. The $P$-values are MCMC $P$-values, but have a similar interpretation as frequentist $P$-values. Management has two levels (organic and conventional), with species has five levels (Coffea, Musa, Erythrina, Coffea-Musa, Coffea-Erythrina), though only four are estimated to avoid multi-collinearity. The coefficient for each can be interpreted as the effect of the given species composition relative to the other four. Values in bold are significant at $P<0.05$
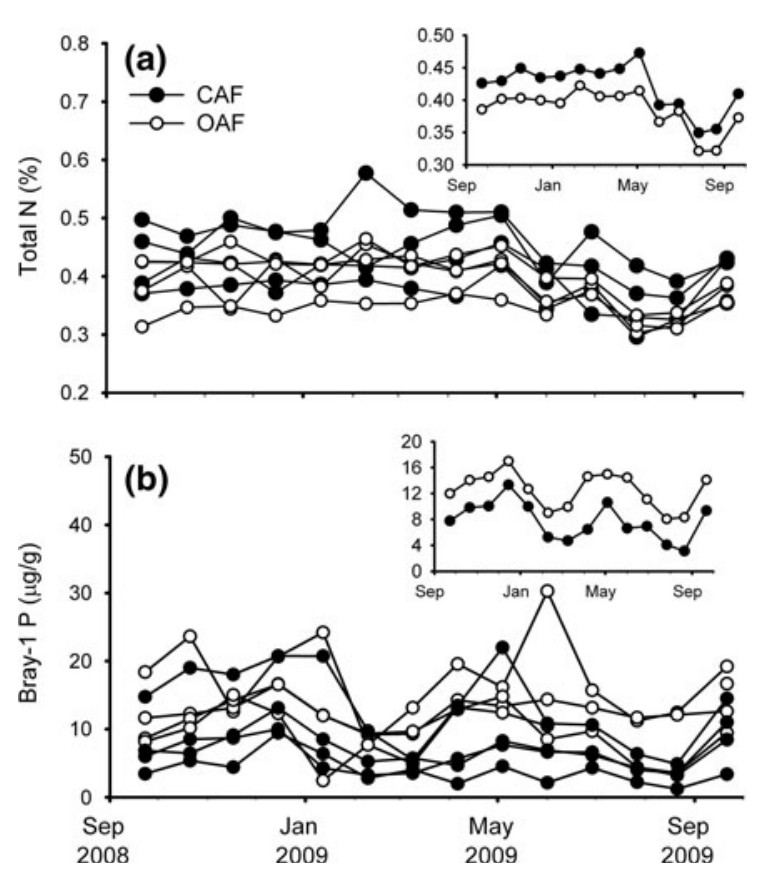

Fig. 5 Soil $\mathrm{N}$ and $\mathrm{P}$ in top $10 \mathrm{~cm}$ in coffee agroforests in Costa Rica. Mean a total $\mathrm{N}$ and $\mathbf{b}$ Bray-1 P in soils collected from 0 to $10 \mathrm{~cm}$ in organic and conventional coffee agroforests (across species) throughout the study period (September 2008-October 2009). Closed circles indicate conventional agroforests (CAF; $n=4$ ), and open circles indicate organic agroforests (OAF; $n=4$ ). Inset of mean soil $\mathrm{N}$ and $\mathrm{P}$ dynamics across farms are also presented

$0.14 \mathrm{mg}$ organic $\mathrm{P} \mathrm{L}^{-1}$ across other species; $P=0.05$; Table 3).

Although there were no significant effects of fertilizer type on surface soils, we observed strong species effects on soil characteristics. Total soil $\mathrm{C}$ and $\mathrm{N}$ concentrations were significantly higher (by $14 \%$ ) in the Coffea-Erythrina combination than in Coffea-Musa or in Coffea alone ( $P<0.0001$ in both cases; Table 4). Bray $\mathrm{P}$ concentrations were significantly lower (by $25 \%$ ) under Coffea plants alone than in combination with either Erythrina or Musa $(P=0.03$ and $P=0.02$, respectively; Table 4). Gravimetric soil moisture was significantly lower (by $7 \%$ ) under Coffea-Erythrina combinations than Coffea-Musa combinations or Coffea alone $(P=0.01$ and $P<0.0001$, respectively). Finally, soil $\mathrm{pH}$ was significantly higher (by $10 \%$ ) under the Coffea-Musa combination $(P<0.0001)$ compared to other species (Table 4).

\section{Effects of soil characteristics on nutrient concentrations in leachate}

We wanted to determine if leachate concentrations could be predicted by surface soil nutrient concentrations and properties. Inorganic $\mathrm{PO}_{4}{ }^{3-}-\mathrm{P}$ concentrations in leachate (in gravity lysimeters at $15 \mathrm{~cm}$ ) were negatively correlated with $\mathrm{pH}(P<0.0001$, $r=-0.22$ ). Organic P concentrations in leachate (at $15 \mathrm{~cm})$ were significantly positively correlated with $\mathrm{C}: \mathrm{N}$ in soils $(P<0.0001, r=0.24)$.

\section{Discussion}

Management affects leachate but not soil

Fertilizer $\mathrm{N}$ inputs were three times higher in the monoculture farm compared to the agroforests (see 
Table 4 Soil characteristics among species $(0-10 \mathrm{~cm})$ averaged across study period

\begin{tabular}{|c|c|c|c|c|c|c|c|}
\hline Species & $\begin{array}{l}\text { Total } \\
\text { C }(\%)\end{array}$ & $\begin{array}{l}\text { Total } \mathrm{N} \\
(\%)\end{array}$ & $\mathrm{C}: \mathrm{N}$ & $\begin{array}{l}\text { Bray-1 P } \\
(\mu \mathrm{g} / \mathrm{g})\end{array}$ & $\begin{array}{l}\text { Gravimetric soil } \\
\text { moisture }(\%)\end{array}$ & $\mathrm{pH}$ & $\begin{array}{l}\text { Bulk density } \\
\left(\mathrm{g} / \mathrm{cm}^{3}\right)\end{array}$ \\
\hline Coffea & $4.4(0.09) \mathrm{a}$ & $0.38(0.005) \mathrm{a}$ & $14(0.15)$ & $8.3(0.59) \mathrm{a}$ & $59.4(1.0) \mathrm{a}$ & $5.1(0.07) \mathrm{a}$ & $0.87(0.03)$ \\
\hline Coffea + Musa & $4.8(0.12) \mathrm{a}$ & $0.40(0.007) \mathrm{a}$ & $14(0.19)$ & $11.1(0.82) \mathrm{b}$ & $61.0(1.0) \mathrm{a}$ & $5.6(0.08) b$ & $0.88(0.04)$ \\
\hline Coffea + Erythrina & $5.2(0.15) \mathrm{b}$ & $0.44(0.009) \mathrm{b}$ & $14(0.15)$ & $10.9(0.77) \mathrm{b}$ & $66.0(1.5) \mathrm{b}$ & $5.0(0.06) \mathrm{a}$ & $0.86(0.03)$ \\
\hline
\end{tabular}

Differences in nutrient concentrations, soil moisture ( mass $_{\text {water }} / \mathrm{mass}_{\text {soil }}$ ), and $\mathrm{pH}$ among the three species combinations were tested by LMM. Means are reported for each species $( \pm \mathrm{SE})$, and values that were significantly different at $P<0.05$ are indicated by different letters. Bulk density values are provided for scaling purposes

Fig. 6 Conceptual diagram of the relationships between nutrient inputs and species and structural diversity on soil characteristics and leachate concentrations in organic agroforests (OAF), conventional agroforests (CAF), and conventional monocultures (MONO). The size of arrows are indicative of the magnitude of the flux

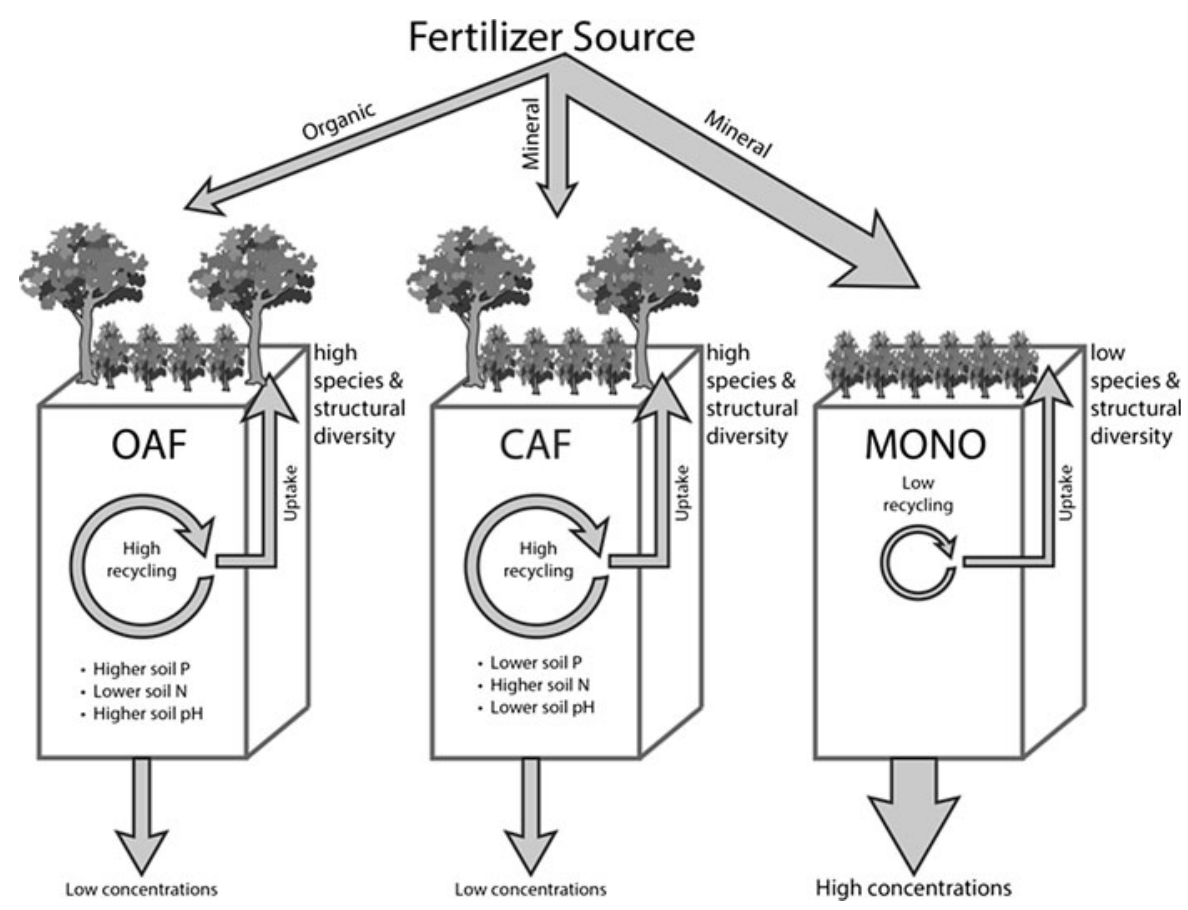

Table 5 Soil characteristics between conventional and organic agroforests $(0-10 \mathrm{~cm})$ averaged across study period

\begin{tabular}{llllllll}
\hline Management & Total C (\%) & $\begin{array}{l}\text { Total N } \\
(\%)\end{array}$ & C:N & $\begin{array}{l}\text { Bray-1 P } \\
(\mu \mathrm{g} / \mathrm{g})\end{array}$ & $\begin{array}{l}\text { Gravimetric soil } \\
\text { moisture }(\%)\end{array}$ & $\begin{array}{l}\mathrm{pH} \\
\left(\mathrm{g} / \mathrm{cm}^{3}\right)\end{array}$ \\
\hline Organic & $4.5(0.12)$ & $0.39(0.005)$ & $14(0.14)$ & $12.5(0.70)$ & $60.3(0.009)$ & $5.4(0.06)$ & $0.88(0.03)$ \\
Conventional & $5.1(0.08)$ & $0.42(0.007)$ & $13(0.12)$ & $8.0(0.45)$ & $63.8(0.011)$ & $5.0(0.06)$ & $0.82(0.02)$ \\
\hline
\end{tabular}

Differences in nutrient concentrations, soil moisture $\left(\right.$ mass $_{\text {water }} /$ mass $\left._{\text {soil }}\right)$, and $\mathrm{pH}$ between the management types were tested by LMM. Means are reported for each species $( \pm \mathrm{SE})$, and no significant differences were detected between management types. Bulk density values are provided for scaling purposes

Table 1). Therefore, it is not surprising that leachate $\mathrm{NO}_{3}{ }^{-}-\mathrm{N}$ concentrations were higher in the monoculture than the agroforests (tension lysimeters, at 15 and $100 \mathrm{~cm}$; Fig. 3a). Further, although $\mathrm{NO}_{3}{ }^{-}-\mathrm{N}$ concentrations were significantly reduced at depth in the monoculture, due to its (1) high $\mathrm{N}$ inputs, and (2) reduced plant uptake (no trees), concentrations exceeded the public health standard limit (WHO 1996; Figs. 3a, 6). Nitrate concentrations in gravity lysimeters $(15 \mathrm{~cm})$ were significantly higher in conventional compared to organic agroforests (Fig. 4a), and it should be noted that although not significant in 
the tension lysimeters, this trend was still apparent at $15 \mathrm{~cm}$ depth. Elevated $\mathrm{NO}_{3}{ }^{-}-\mathrm{N}$ concentrations in shallow leachate concentrations are likely driven by the larger $\mathrm{N}$ inputs in conventional agroforests through mineral fertilizers. However, $\mathrm{NO}_{3}{ }^{-}-\mathrm{N}$ concentrations at $100 \mathrm{~cm}$ in the organic and conventional agroforests were very similar and below the standard limit. Even though conventional agroforests received about 2.5 times as much $\mathrm{N}$ as organic agroforests, $\mathrm{NO}_{3}{ }^{-}-\mathrm{N}$ concentrations were very similar at $100 \mathrm{~cm}$, which suggests that trees (density was also similar among agroforests) can draw concentrations down to around $8 \mathrm{mg} \mathrm{NO}_{3}{ }^{-}-\mathrm{N} \mathrm{L}^{-1}$ (a concentration that is still higher than found in near-by tree plantations $(0.66 \mathrm{mg}$ $\mathrm{NO}_{3}{ }^{-}-\mathrm{N} \mathrm{L}^{-1}$; Ewel and Bigelow 2011; Fig. 6). The similarity among agroforests receiving different forms and amounts of inputs suggests that may trees have a "neutralizing effect", and lower concentrations to levels which meet drinking water standards for nitrate (WHO 1996).

Although two orders of magnitude lower than nitrate concentrations, leachate organic $\mathrm{P}$ concentrations varied among farm management types. The monoculture received over three and a half times as much fertilizer $\mathrm{P}$ as the agroforests, and lost about three times as much $\mathrm{P}$, primarily in organic form (at $15 \mathrm{~cm}$; Fig. 3c). Although fertilizer was added in inorganic form in the monoculture, studies have shown that the application of fertilizer $\mathrm{N}$ tends to increase P leaching and that up to $80 \%$ of the total P lost is in organic form (Monaghan et al. 2000, 2002). Unlike $\mathrm{N}, \mathrm{P}$ concentrations in leachate were neither lower at depth nor different among management types at depth. Phosphorus is very conservatively cycled in tropical soils (Jordan 1982; Vitousek 1984), and P in solution is quickly adsorbed onto clay minerals. Thus organic $\mathrm{P}$ concentrations in leachate appear to be driven by inherent chemical mechanisms, which may also explain why solutions are similar at 15 and $100 \mathrm{~cm}$. In these systems, it seems that regardless of management, additional $\mathrm{P}$ is either (1) being adsorbed onto clay minerals and effectively removed from the $\mathrm{P}$ cycle (Uehara and Gillman 1981), and/or (2) quickly assimilated by plants and microbes.

Although we observed significant effects of management on leachate concentrations, this was not the case for soil properties (Fig. 5; Table 5; Fig. 9 in Appendix). Due to the formulation of the statistical model, the effects of species overwhelm any management effects. Nevertheless, some trends are apparent. Soil $\mathrm{P}$ tends to be higher in organic agroforests where soil $\mathrm{N}$ tends to be higher in conventional agroforests (Fig. 6). This pattern is significant at deeper soil layers on these farms (Tully et al. 2013). Higher soil $\mathrm{N}$ in conventional agroforests is likely the result of greater $\mathrm{N}$ inputs and subsequent transport (via leaching) to deeper soil layers. Higher soil $\mathrm{P}$ in conventional farms may be due to lower yields (Tully and Lawrence 2011) and therefore lower demand of $\mathrm{P}$ compared to higher yielding conventional agroforests (see Tully et al. 2013).

Temporal variation in leachate and soils

Shallow leachate concentrations increased slightly in January following the first prune and during fertilization. However, the highest $\mathrm{NO}_{3}{ }^{-}-\mathrm{N}$ concentrations followed the prolonged dry period (Fig. 4a). High rates of mineralization and nitrification are often observed in topsoil with the onset of rains (known as the "birch effect"; Birch 1964; Chikowo et al. 2004). The birch effect may explain the sudden pulse in $\mathrm{NO}_{3}{ }^{-}-\mathrm{N}$ concentrations that we observed at the beginning of the rainy season. As fertilizer is typically added in January, it is unlikely that this pulse is the result of fertilizer application, although it is possible that residual water-soluble fertilizer $\mathrm{NO}_{3}{ }^{-}-\mathrm{N}$ is mobilized when water passes through the soil.

Phosphate (and ammonium) concentrations increased tenfold during the driest period (about one month before the peak in $\mathrm{NO}_{3}{ }^{-}-\mathrm{N}$ concentrations; Fig. 4c). As $\mathrm{PO}_{4}{ }^{3-}-\mathrm{P}$ is tightly bound to soil colloids, and only a small fraction is mobile, in a typical month this soluble fraction was diluted to a mean concentration of $0.08 \mathrm{mg} \mathrm{PO}_{4}{ }^{3-}-\mathrm{P} \mathrm{L}^{-1}$. However, in dry months $(<3.5 \mathrm{~mm}$ rainfall per day) soluble $\mathrm{P}$ was diluted in less water leading to higher concentrations at the end of the dry period $\left(0.31 \mathrm{mg} \mathrm{PO}_{4}{ }^{3-}-\mathrm{P} \mathrm{L}^{-1}\right)$.

Temporal variations in soil $\mathrm{C}, \mathrm{N}$, and $\mathrm{P}$ tracked plant nutrient demand. The draw-down of soil $\mathrm{N}$ and $\mathrm{P}$ between June and September may be the result of enhanced Coffea uptake as the crop matures (i.e. berries ripen), which appears to demand high quantities of nutrients. Soil P also declined from January to April, increasing again in May. This pattern may be better explained by changes in soil chemistry as a result of nutrient additions in the form of pruning residues (December/January) and fertilizer (January/February). 
Following nutrient inputs, microbial and plant activity increases, and in tropical soils, $\mathrm{P}$ often limits plant and microbial uptake of other nutrients (Vitousek 1982), which may explain why soil $\mathrm{P}$ declined following nutrient additions, but soil $\mathrm{N}$ remained high. This is further supported by the fact that decomposition of pruning residues is P-limited, especially in the initial stages (Tully and Lawrence 2012).

\section{Higher concentrations in tension lysimeters}

Nitrate concentrations were higher in tension lysimeters than in gravity lysimeters, which may be due, in part, to the sampling protocol. Monthly water collection from tension lysimeters may not have captured some of the short-term variations in leachate concentrations that may follow large rainfall events (dilution of nutrient concentrations) or management interventions such as fertilizer application and shade tree pruning (sudden spikes in nutrient concentrations). Gravity lysimeters, on the other hand, provide an "average" concentration across the month as the bottles continuously collect water across that time period. Tension lysimeters use suction to collect leachate, which allows for the water sampling even during relatively dry periods (when no water may be moving vertically through the soil column). Therefore, tension lysimeters have access to the more concentrated solutions that tend to occur during dry periods.

Species affect leachate and soil

Farmers are keenly aware of the benefits imparted by the presence of N-fixers (Albertin and Nair 2004). Enhanced $\mathrm{N}$ availability in the soil (Table 4) and higher concentrations in soil solution under Erythrina trees is the result of $\mathrm{N}$-fixation and subsequent transfer of fixed $\mathrm{N}$ partly through high quality leaves during annual prunings (see Payán et al. 2009 for more detailed spatial effects). Erythrina leaves have high $\mathrm{N}$ and $\mathrm{P}$ concentrations and decompose quickly, rapidly releasing nutrients to the soil (Tully and Lawrence
2012). Nitrogen fixed by Erythrina may elevate surface soil solution concentrations, potentially transferring more $\mathrm{N}$ to deeper soil layers.

The elevated organic $\mathrm{P}$ concentrations found in leachate under Coffea-Erythrina combinations suggest that Erythrina may play an important role in $\mathrm{P}$ cycling (Tully and Lawrence 2012), potentially as a result of mychorrhizal activity (Danso et al. 1992). For example, bioavailable soil $\mathrm{P}$ was higher under Coffea near shade trees compared to distant Coffea plants. Phosphorus availability may be greater in species mixtures as mychorrizal fungi are capable of liberating $\mathrm{P}$ not available to plants through enhanced mineral weathering (Jongmans et al. 1997) and by associating with bacteria that secrete phosphatases or excrete organic acids (Smith et al. 1997). In addition, greater quantities of nutrient-rich litter and pruning residues can be produced under species mixtures, which may enhance the quality of surrounding soils over time. For example, initial P-release from decomposing Coffea leaves is much higher when mixed with Musa and Erythrina (Tully and Lawrence 2012). The higher concentrations of both $\mathrm{C}$ and $\mathrm{N}$ in soils under the Coffea-Erythrina combinations (Table 4) further support the theory that the presence of multiple species (especially $\mathrm{N}$-fixers) can improve soil quality.

Soil characteristics do not predict leachate concentrations

Available soil $\mathrm{P}$ was a good predictor of inorganic $\mathrm{PO}_{4}{ }^{3-}-\mathrm{P}$ in leachate at $15 \mathrm{~cm}$ suggesting that Bray extractions may be useful in determining concentrations of $\mathrm{P}$ in shallow leachate. However, we did not identify any surface soil properties that were able to predict nutrient concentrations at depth. Potassium chloride $(\mathrm{KCl})$ is used to extract soil $\mathrm{N}$ and predict $\mathrm{NO}_{3}{ }^{-}-\mathrm{N}$ concentrations in leachate. Although we did not perform $\mathrm{KCl}$ extractions, we expect that the surface concentration of $\mathrm{KCl}$-extractable $\mathrm{N}$, will not likely make a good proxy for deep leachate concentrations. 


\section{Conclusions}

Both farm management and species composition affected leachate nutrient concentrations and soil properties in coffee agroecosystems. Overall, the monoculture farm, which received higher fertilizer $\mathrm{N}$, also had higher nutrient concentrations in leachate than the agroforests. At depth, agroforests had very similar concentrations of nutrients in leachate despite large differences in nutrient inputs, which suggests that the presence of trees may draw concentrations down to levels that meet the WHO standards for drinking water. Both soil and leachate nutrient concentrations were elevated under the $\mathrm{N}$-fixing species, supporting the critical role this functional group plays in sustaining agroforests. Finally, the soil nutrient concentrations $(\mathrm{C}, \mathrm{N}$, and $\mathrm{P}$ ) and properties (soil moisture and $\mathrm{pH}$ ) we measured were not strong predictors of nutrient concentrations in leachate.

Acknowledgments We would like to acknowledge the financial contributions of the Jefferson Scholars Foundation, the Raven Society, the Bankard Fund for Political Economy, the Center for Undergraduate Excellence, and the University of Virginia, to this research. Gabriela Soto facilitated the logistics of the fieldwork. We are grateful to our field and lab team at CATIE: Alejandra Hernández Guzmán, Amanda Schwantes, Blanca Salguero Londoño, Mauricio Scheelje, and Patricia Leandro. Finally, we would like to acknowledge the farmers of San Juan Norte, San Juan Sur, and Colorado for giving us access to their farms and welcoming us into their homes.

\section{Appendix}

See Figs. 7, 8, 9.

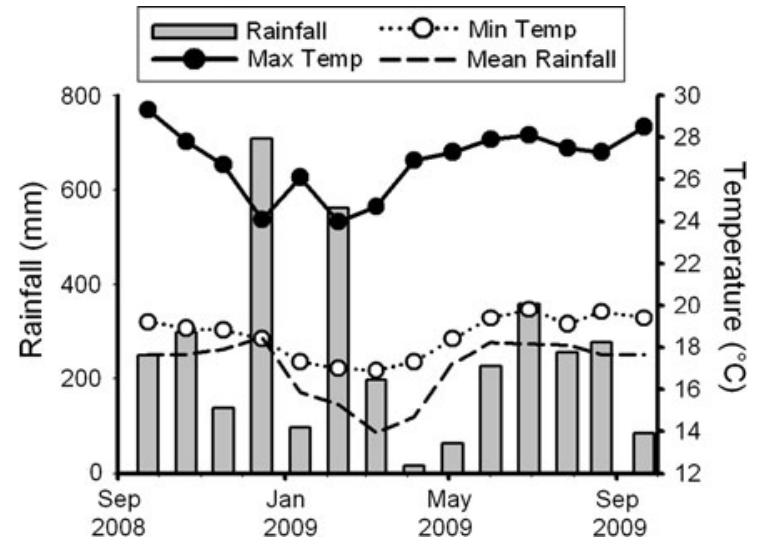

Fig. 7 Rainfall and temperature throughout the study period (September 2008-October 2009) in the Central Valley of Costa Rica. Cumulative rainfall and mean daily minimum and maximum temperatures for each 28-day period prior to sample collection. Dashed line represents the mean monthly rainfall from 1942-2009 (CATIE meteorological data)

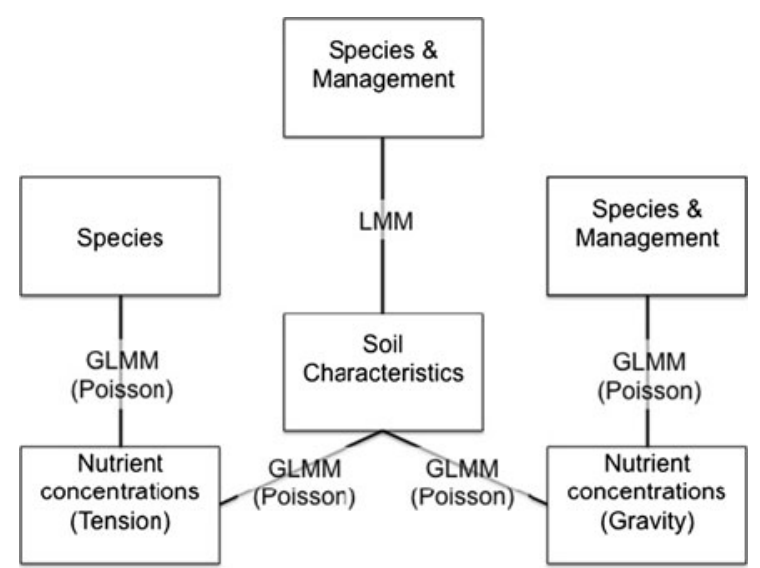

Fig. 8 Each statistical model run during the analysis. The boxes represent key variables. The lines connect the response variables, which are higher up, to the dependent variables, which are lower in the diagram. The text describes the type of linear model used 
Fig. 9 Soil $\mathrm{C}, \mathrm{pH}$, and soil moisture in the top $10 \mathrm{~cm}$ in coffee agroforests in Costa Rica. Mean a total $\mathbf{C}, \mathbf{b} \mathrm{pH}$, and $\mathbf{c}$ gravimetric soil moisture in soils collected from 0 to $10 \mathrm{~cm}$ in organic and conventional coffee agroforests (across species) throughout the study period (September 2008-October 2009). Closed circles indicate conventional agroforests (CAF; $n=4$ ), and open circles indicate organic agroforests $(\mathrm{OAF}$; $n=4)$. Inset of mean soil C, $\mathrm{pH}$, and moisture dynamics across farms are also presented

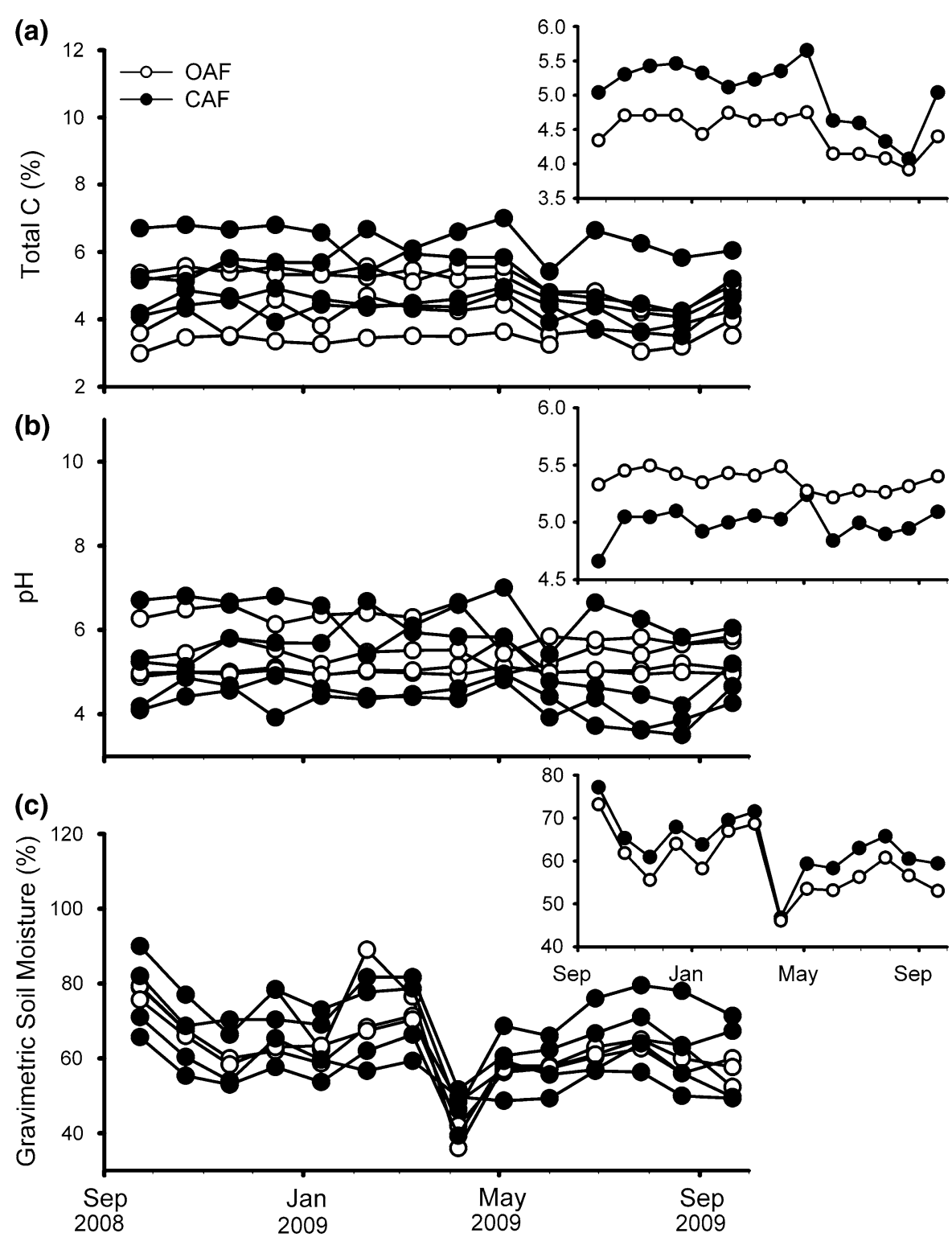

\section{References}

Albertin A, Nair PKR (2004) Farmers' perspectives on the role of shade trees in coffee production systems: an assessment from the Nicoya peninsula, Costa Rica. Hum Ecol 32:443-463. doi:10.1023/B:HUEC.0000043515.84334.76

Araya M (2005) Stratification and spatial distribution of the banana (Musa AAA, Cavendish subgroup, cvs' Valery'and Grande naine') root system. In: Turner DW, Rosales FE (eds) Banana root system: towards a better understanding for its productive management. Proceedings of an International Symposium, San José, Costa Rica, 3-5 November 2003, pp 83-103

Aronsson H, Torstensson G, Bergström L (2007) Leaching and crop uptake of $\mathrm{N}, \mathrm{P}$ and $\mathrm{K}$ from organic and conventional cropping systems on a clay soil. Soil Use Manag 23:71-81. doi:10.1111/j.1475-2743.2006.00067

Baayen RH, Davidson DJ, Bates DM (2008) Mixed-effects modeling with crossed random effects for subjects and items. J Mem Lang 59:390-412. doi:10.1016/j.jml.2007. 12.005

Babbar LI, Zak DR (1995) Nitrogen loss from coffee agroecosystem in Costa Rica: leaching and denitrification in the presence and absence of shade trees. J Environ Qual 24:227-233

Berendse F (1979) Competition between plant populations with different rooting depths I. Theoretical considerations. Oecologia 43:19-26. doi:10.1007/BF00346669

Birch HF (1964) Mineralisation of plant nitrogen following alternate wet and dry conditions. Plant Soil 20:43-49 
Bradford MA, Wood SA, Maestre FT, Reynolds JF, Warren RJ (2012) Contingency in ecosystem but not plant community response to multiple global change factors. New Phytol 196:462-471. doi:10.1111/j.1469-8137.2012.04271.x

Bray RM, Kurtz LT (1945) Determination of total organic and available forms of phosphorus in soils. Soil Sci 59:39-45

Bremer C, Braker G, Matthies D, Reuter A, Engels C, Conrad R (2007) Impact of plant functional group, plant species, and sampling time on the composition of nirK-type denitrifier communities in soil. Appl Environ Microb 73:6876-6884

Browne WJ, Draper D (2006) A comparison of Baysian and likelihood-based methods for fitting multilevel models. Bayesian Anal 3:473-514

Campo J, Maas M, Jaramillo VJ, Martnez-Yrizar A, Sarukhan J (2001) Phosphorus cycling in a Mexican tropical dry forest ecosystem. Biogeochemistry 53:161-179. doi:10.1023/A: 1010663516029

Cardinale BJ, Wright JP, Cadotte MW, Carroll IT, Hector A, Srivastava DS, Loreau M, Weis JJ (2007) Impacts of plant diversity on biomass production increase through time because of species complementarity. Proc Natl Acad Sci USA 104:18123

Cardinale BJ, Duffy JE, Gonzalez A, Hooper DU, Perrings C, Venail P, Narwani A, Mace GM, Tilman D, Wardle DA (2012) Biodiversity loss and its impact on humanity. Nature 486:59-67

Carney KM, Matson PM (2004) Microorganisms, and soil carbon cycling: does altering the world belowground matter to ecosystem functioning? Ecosystems 8:928-940

Chesney P (2008) Nitrogen and fine root length dynamics in a tropical agroforestry system with periodically pruned Erythrina poeppigiana. Agrofor Syst 72:149-159. doi: 10.1007/s10457-007-9064-7

Chikowo R, Mapfumo P, Nyamugafata P, Giller KE (2004) Maize productivity and mineral $\mathrm{N}$ dynamics following different soil fertility management practices on a depleted sandy soil in Zimbabwe. Agr Ecosyst Environ 102:119-131

Clark J (2005) Why environmental scientists are becoming Bayesians. Ecol Lett 8:2-14. doi:10.1111/j.1461-0248. 2004.00702.x

Clark KL, Nadkarni NM, Schaefer D, Gholz HL (1998) Atmospheric deposition and net retention of ions by the canopy in a tropical montane forest, Monteverde, Costa Rica. J Trop Ecol 14:27-45

Clark MS, Horwath WR, Shennan C, Scow KM, Lantni WT, Ferris H (1999) Nitrogen, weeds and water as yield-limiting factors in conventional, low-input, and organic tomato systems. Agr Ecosyst Environ 73:257-270. doi:10.1016/ S0167-8809(99)00057-2

Danso S, Bowen GD, Sanginga N (1992) Biological nitrogen fixation in trees in agro-ecosystems. Plant Soil 14:177-196. doi:10.1007/BF00011316

Draye X (2002) Banana roots: architecture and genetics. In: Waisel Y, Eshel A, Kafkafi U (eds) Plant roots: the hidden half, 3rd edn. Marcel Dekker, New York, pp 261-277

Drinkwater LE, Letourneau DK, Workneh F, Van Bruggen AHC, Shennan C (1995) Fundamental differences between conventional and organic tomato agroecosystems in California. Ecol Appl 5:1098-1112

Eviner VT, Chapin FS III (2003) Functional matrix: a conceptual framework for predicting plant effects on ecosystem processes. Annu Rev Ecol Syst 34:455-485. doi: 10.1146/annurev.ecolsys.34.011802.132342

Ewel JJ, Bigelow SW (2011) Tree species identity and interactions with neighbors determine nutrient leaching in model tropical forests. Oecologia 167:1127-1140

Fließach A, Mader P (2000) Microbial biomass and size-density fractions differ between soils of organic and conventional agricultural systems. Soil Biol Biochem 32:757-768. doi: 10.1016/S0038-0717(99)00197-2

Fließach A, Oberholzer H-R, Gunst L, Mader M (2007) Soil organic matter and biological soil quality indicators after 21 years of organic and conventional farming. Agr Ecosyst Environ 118:273-284. doi:10.1016/j.agee.2006.05.022

Goméz-Delgado F, Roupsard O, le Maire G, Taugourdeau S, Pérez A, can Oijen M, Vaast P, Rapidel B, Harmand JM, Voltz M, Bonnefond JM, Imbach JP, Moussa R (2011) Modelling the hydrological behaviour of a coffee agroforestry basin in Costa Rica. Hydrol Earth Syst Sci 15:369-392

Hadfield JD (2010) MCMC methods for multi-response generalized linear mixed models: the MCMCglmm R package. J Stat Softw 33:1-22

Harmand JM, Avila H, Dambrine E, Skiba U, de Miguel S, Renderos RV, Oliver R, Jimenez F, Beer J (2007) Nitrogen dynamics and soil nitrate retention in a Coffea arabicaEucalyptus deglupta agroforestry system in Southern Costa Rica. Biogeochemistry 85:125-139. doi:10.1007/s10533007-9120-4

Hillebrand H, Matthiessen B (2009) Biodiversity in a complex world: consolidation and progress in functional biodiversity research. Ecol Lett 12:1405-1419

Hosomi M, Sudo R (1986) Simultaneous determination of total nitrogen and total phosphorus in freshwater samples using persulfate digestion. Int J Envion Stud 27:267-275

Hurlbert SH, Lombardi CM (2009) Final Collapse of the Neyman-Pearson Decision Theoretic Framework and Rise of the neoFisherian. Ann Zool Fennici 46:311-349

Innes L, Hobbs PJ, Bardgett RD (2004) The impacts of individual plant species on rhizosphere microbial communities in soils of different fertility. Biol Fertility Soils 40:7-13

Jongmans AG, Van Breemen N, Lundström U, Van Hees PAW, Finlay RD, Srinivasan M, Unestam T, Giesler R, Melkerud PA, Olsson M (1997) Rock-eating fungi. Nature 389: 682-683

Jordan CF (1982) The nutrient balance of an Amazonian rainforest. Ecology 63:647-654

Lamb EG, Kennedy N, Siciliano SD (2011) Effects of plant species richness and evenness on soil microbial community diversity and function. Plant Soil 338:483-495

Liebig MA, Doran JW (1999) Impact of organic production practices on soil quality indicators. J Environ Qual 28: 1601-1609

Monaghan RM, Paton RJ, Smith LC, Binet C (2000) Nutrient losses in drainage and surface runoff from a cattle-grazed pasture in Southland. Proc N Z Grassland Assoc 62:99-104

Monaghan RM, Paton RJ, Drewry JJ (2002) Nitrogen and phosphorus losses in mole and tile drainage from a cattlegrazed pasture in eastern Southland. N Z J Agr Res 45: 197-205

Payán F, Jones DL, Beer J, Harmand JM (2009) Soil characteristics below Erythrina poeppigiana in organic and 
conventional Costa Rican coffee plantations. Agrofor Syst 76:81-93. doi:10.1007/s10457-008-9201-y

Radulovich R, Sollins S (1991) Nitrogen and phosphorus leaching in zero-tension drainage from a humid tropical soil. Biotropica 23:84-87

R Development Core Team (2012) R: A Language and environment for statistical computing. In: $\mathrm{R}$ Development Core Team (ed) A language and environment for statistical computing. R Foundation for Statistical Computing, Vienna

Reganold JP, Palmer AS, Lockhart JC, Macgregor AN (1993) Soil quality and financial performance of biodynamic and conventional farms in New Zealand. Science 260:344. doi: 10.1126/science. 260.5106 .344

Reich PB, Tilman D, Isbell F, Mueller K, Hobbie SE, Flynn DFB, Eisenhauer N (2012) Impacts of biodiversity loss escalate through time as redundancy fades. Science 336:589-592

Reynolds-Vargas JS, Richter DD (1995) Nitrate in groundwaters of the Central Valley, Costa Rica. Environ Int 21:71-79. doi:10.1016/0160-4120(94)00034-5

Russell AE, Ewel JJ (1985) Leaching from a tropical andept during big storms: a comparison of three methods. Soil Sci 139:181-189

Salas R, Bornemisza E, Zapata F, Chaves V, Rivera A (2002) Absorcion del fertilizante nitrogenado por la planta de café y su influencia sobre la contaminacion de las aguas subterraneas. Manejo Integrado de Aguas Subterraneas. EUNED, San José, Costa Rica, pp 89-104

Schroth G, Salazar E, Da Silva JP (2001) Soil nitrogen mineralization under tree crops and a legume cover crop in multistrata agroforestry in Central Amamzonia: spatial and temporal patterns. Exp Agr 37:253-367. doi:10.1017/ S0014479701002058

Selvaradjou SK, Montanarella L, Spaargaren O, Dent D (2005) European Digital Archive of Soil Maps (EuDASM) - Soil Maps of Latin America and Caribbean Islands. Office of the Official Publications of the European Communities, Luxembourg

Seyfried MS, Rao PSC (1991) Nutrient leaching from two contrasting cropping systems in the humid tropics. Trop Agr 68:9-18

Siles P, Harmand JM, Vaast P (2010) Effects of Inga densiflora on the microclimate of coffee (Coffea arabica L.) and overall biomass under optimal growing conditions in Costa Rica. Agrofor Syst 78:269-286

Smith T, Shugart HH, Woodward FI (1997) Plant functional types. Cambridge University Press, Cambridge

Sommer K (1978) Use of radioisotopes in agriculture. Report to the Government of Costa Rica Internal Atomic Energy Agency, Vienna

Stopes C, Lord EI, Phillips L, Woodward L (2002) Nitrate leaching from organic farms and conventional farms following best practice. Soil Use Manag 18:256-263. doi: 10.1111/j.1475-2743.2002.tb00267.x

Torstensson G, Aronsson H, Bergstrom L (2006) Nutrient use efficiencies and leaching of organic and conventional cropping systems in Sweden. Agron J 98:603-615. doi: 10.2134/agronj2005.0224

Tully KL, Lawrence D (2011) Closing the loop: nutrient balances in organic and conventional coffee agroforests. J Sust Agr 35:671-695. doi:10.1080/10440046.2011.586599

Tully KL, Lawrence D (2012) Canopy and leaf composition drive patterns of nutrient release from pruning residues in a coffee agroforest. Ecol App 22(4):1330-1344

Tully KL, Lawrence D, Wood SW (2013) Organically managed coffee agroforests have larger soil phosphorus but smaller soil nitrogen pools. Biogeochemistry doi:10.1007/s10533013-9842-4

Tully KL, Lawrence D, Scanlon TM (2012) More trees less loss: nitrogen leaching losses decrease with increasing biomass in coffee agroforests. Agr Ecosyst Environ 161:137-144. doi:10.1890/10-2342.1

Uehara G, Gillman GP (1981) The mineralogy, chemistry and physics of tropical soils with variable charge clays. Westview Press, Boulder

Ulén B, Aronsson H, Torstensson G, Mattsson L (2005) Phosphorus and nitrogen turnover and risk of waterborne phosphorus emissions in crop rotations on a clay soil in southwest Sweden. Soil Use Manag 21:221-230. doi: 10.1111/j.1475-2743.2005.tb00128.x

Van Noordwijk M, Lawson G, Soumare A, Groot JJR, Hairiah K (1996) Root distribution of trees and crops: competition and/or complementarity. In: Ong CK, Huxley P (eds) Treecrop interactions: a physiological approach. CAB International, Wallingford. pp 319-364

Vanlauwe B, Sanginga N, Merckx R (1997) Decomposition of four Leucaena and Senna prunings in alley cropping systems under sub-humid tropical conditions: the process and its modifiers. Soil Biol Biochem 29:131-137. doi: 10.1016/S0038-0717(96)00301-X

Vitousek PM (1982) Nutrient cycling and nutrient use efficiency. Am Nat 119:553-573

Vitousek PM (1984) Litterfall, nutrient cycling, and nutrient limitation in tropical forests. Ecology 65:285-298. doi: $10.2307 / 1939481$

World Health Organization (1996) Guidelines for drinking water quality, vol. 2, 2nd ed. Health criteria and other supporting information. World Health Organization, Geneva, pp 313-324

Zuur AF, Ieno EN, Walker N, Saveliev AA, Smith GM (2009) Mixed Effects Models and Extensions in Ecology with R. Springer, New York 